\title{
SUSCEPTIBILITY OF LABORATORY RATS AND GUINEA-PIGS TO INFECTIOUS BURSAL DISEASE VIRUS INFECTION
}

\author{
J.O.A. OKOYE
}

Department of Veterinary Pathology and Microbiology, University of Nigeria, Nsukka, Nigeria

Received June 10, 1986

\begin{abstract}
$0 \mathrm{k}$ o y e J.0.A.: Susceptibility of Laboratory Rats and Guinea-pigs to Infectious Bursal Disease Virus

Infection. Acta vet. Brno,56,1987:167-171.

Young laboratory Wistar rats and guinea-pigs were infected intraocularly and orally with infectious bursal disease virus (IBDV) suspension which had bursal lesion 50 $10^{4.8}$ per $0.5 \mathrm{ml}$. Neither clinical signs nor gross or histopathological changes were observed. Visceral suspensions were negative for IBVD antigen 3 and 4 days post infection (PI) in agar gel diffusion precipitation test (AGDT). Faecal samples collected 1 - 3 days PI were also negative for IBDV antigen in AGDT. But 2 out of 3 guinea-pig sera collected 14 days PI were positive for IBDV precipitins while rat sera were negative. These observations show that IBDV infection in guinea-pigs could be subclinical.
\end{abstract}

Agar gel diffusion precipitation test, serum, viscera, faeces, post-infection days.

Infectious bursal disease (IBD) is primarily a disease of the domestic fowl ( $0 \mathrm{k}$ o $\mathrm{y} e$ 1984). The infection is subclinical in turkeys (W e $1 \mathrm{~s}-$ $\mathrm{m} a \mathrm{n}$ and $\mathrm{H}$ i $\mathrm{t} \mathrm{ch}$ e $\mathrm{r} 1978$; $\mathrm{M}$ c F e r a n et al. 1980; P e$\mathrm{r}$ e $1 \mathrm{~m} \mathrm{a} \mathrm{n}$ and $\mathrm{H}$ e 11 e r 1981 and 1982; $\mathrm{C} \mathrm{h} \mathrm{u} 1$ and $\mathrm{T}$ h o r s e $\mathrm{n}$ 1984). Guinea-fowls, geese, ducks, quails, bantams and pigeons appear to be resistant ( $\mathrm{H}$ r o s e and $\mathrm{H}$ i r a $i$ 1976; $N$ a wa the et al. 1978; $\mathrm{V} i \mathrm{n}$ d e vog e 1 1979). Reports of infection attempts in rodents which may be involved in the epidemiology of IBD in the farms have been very few. Experimental IBD has been described in mice by $R i \mathrm{n}$ a $1 \mathrm{~d} i$ et al. (1970), $\mathrm{C}$ a m in a r a $t$ a et al. (1979) and B e s t e t o et al. (1980). $0 \mathrm{k} \circ \mathrm{y} e$ and $U \mathrm{c} \mathrm{h}$ e (1986) detected IBD precipitins in the tissues of wild rats killed with traps set in poultry farms with history of previous IBD outbreaks and suggested that the rats could be involved in the spread of IBD among poultry farms. This observation is further investigated in this project in which the response of laboratory rats and guinea-pigs to IBDV infections are studied. 


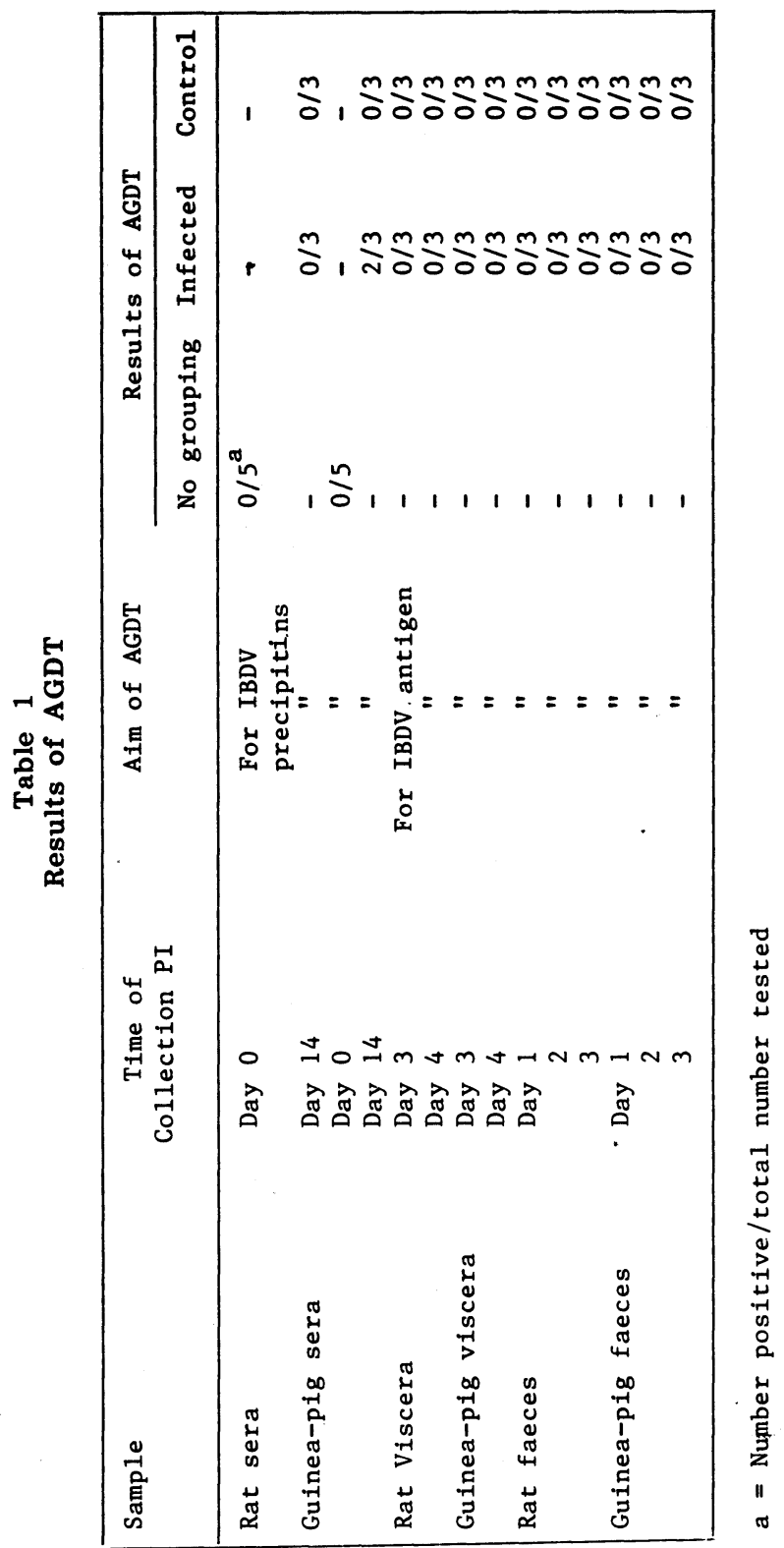




\section{Materials and Methods}

The vir us

The IBD virus (IBDV) was obtained as $20 \%$ phosphate-buffered-saline (PBS) suspension of bursa of Fabricius of chickens that died of field cases of IBD. The suspension was found to have a bursal lesion 50 (BL50) titre of 104.8 per $0.5 \mathrm{ml}$ by method of $R$ e e d and $M u e n c h$ (1938). It was stored at $-20^{\circ} \mathrm{C}$ until used. Young Wistar mice and guinea-pigs were used. Fifteen guinea-pigs were each given a total of $1 \mathrm{ml}$ of the viral suspension intraocularly and orally, while 15 rats were each given a total of $0.4 \mathrm{ml}$ of the inoculum via the same routes. The infected animals were reared separately from the uninfected controls which were the same in number and each was given the PBS diluent equal to the volume of inoculum given to the infected via the same routes.

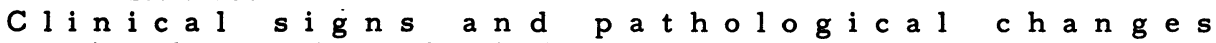

Animals were observed daily for clinical signs. Three in each group were sacrificed on days 3 and 4 post infection (PI) and examined for gross pathological changes. Spleen, thymus and kidney were processed, sectioned and stained with haematoxylin and eosin.

Virus identification in the organs and f a e c e s

Infected and control animals sacrificed on days 3 and 4 PI were eviscerated and a $50 \%$ suspension of the internal organs without the lungs in PBS was prepared separately for each animal and tested for IBDV antigens by agar gel diffusion precipitation test (AGDT). Faecal samples were also collected from each group on days $1-3$ PI. Twenty five 8 suspensions in PBS were prepared and tested for IBDV antigen in AGDT.

$T$ e s $t$ for I B D V p r e c i p i t in $s$

Blood samples were obtained from 5 guinea-pigs and 5 rats just before IBDV inoculation. Samples were also collected 14 day PI from 3 animals in each group. Sera were harvested and inactivated at $56^{\circ} \mathrm{C}$ for $30 \mathrm{~min}$. and tested for IBDV precipitins in AGDT.

A g a g e l diffus ion p r e c i p it a t ion $t$ es $t$

The test was done with the method already described by $0 \mathrm{k} \circ \mathrm{y} e$ and $U \mathrm{z} \circ \mathrm{u} \mathrm{k}$ w (1981). For virus identification tests the positive control was known IBDV antigen while the negative control was normal bursal suspension. But in the tests for IBDV precipitins the positive control was a known IBDV antiserum while the-negative control was a normal serum.

\section{Results}

Neither clinical signs nor gross or histopathological changes were observed in both infected and control groups. Agar gel diffusion tests for IBDV antigen identification in the organs and faeces were all negative for both infected and control animals. In the tests for precipitins in serum samples all the sera from infected and control rats were negative. Two samples out of the 3 from infected guinea-pigs were positive. The details of the serological results are shown in Table 1.

\section{Discussion}

The results of this investigation indicate that IBDV may not be pathogenic 
to rats and guinea-pigs when given orally and intraocularly. Infection in guinea-pigs appeared subclinical while no signs of infection was found in the rats. However, AGDT has been found to be less sensitive than virus isolation and immuno-fluoroscopy methods in the diagnosis of IBDV infection (I d e 1975). This low sensitivity might have affected the results of this experiment. But $\mathrm{O} k \mathrm{k} \mathrm{y}$ and $U \mathrm{ch}$ e (1986) detected IBDV precipitins in wild rat tissues using AGDT. Contrary results in this study could be because the laboratory Wistar rats may be less susceptible or more resistant to IBDV infection than wild rats. There could also be differences in the doses of infection. Detection of serum precipitins in the guinea-pigs support the suggestion that some rodent species which frequent poultry farms may be involved in the spread of $\operatorname{IBD}(O \mathrm{k} \circ \mathrm{y} e$ and $U \mathrm{c} h \mathrm{e}$ 1986). Failure to detect IBDV precipitins in faeces of infected animals could be due to timing of the collection or very limited multiplication of the virus. Further work is still needed to determine the possible role of wild rodents in the epidemiology of IBD, using more sensitive methods.

\section{Citlivost laboratorních potkanů a morčat vůči viru infekční bursitidy}

Mladé laboratorní potkany a morčata byly intraokulárné a orálně infikovány suspenzí viru infekční bursitidy (IBDV) s bursálním indexem $10^{4,8} \mathrm{v} 0,5$ ml. Klinické př́znaky onemocnění ani patohistologické změny pozorovány nebyly. Ve viscerálních orgánech nebyl nalezen IBDV antigen 3 ani 4 dny po infekci za použití precipitace $v$ agarovém gelu. Negativní byly i výsledky vyšetření trusu odebraného 1 - 3 dny po infekci. V krevním séru 2 ze 3 infikovaných morčat byly imunodifuzí prokázány IBDV precipitiny, zatímco séra potkanů byla negativní. Tyto výsledky ukazují, že infekce IBDV může u morčat probíhat bez klinických symptomů.

Чувствительность лабораторных пасюков и морских свинок к вирусу инфекционного бурсита

Молодых лабораторных пасюков и морских свинох инфицировали внутриглазно и перорально суспензией вируса инфекционного бурсита (ИБдВ) с бурсальным индексом 104,8 в 0.5 мл. Клинических признаков заболевания и патогистологических изменений не наблюдали. Во внутренных органах не выявили иБдВ антигена через 3 даже 4 дня после заражения при использовании преципитации в агарном геле. Отрицательными оказались также данные исследований кала, взятого через $1-3$ дня после заражения. В сыворотке крови 2 из 3 инфицированных морских свинох путём иммунодифФузии установили иБдВ преципитины, тогда как сыворотки пасюков оказались отрицательными. Полученные результаты показывают, что инфекция ИЕЛВ может у морских свинок протекатьбез клинических признаков.

\section{Acknowledgement}

The author is grateful to M.C. Ugafor for assistance in the collection of some samples from the experimental animals. 


\section{References}

BESTETTO, G.: - CAMMARATA, G. - CAMMARATA, M.P. - RAMPIN, T.: U1trastructura1 aspects of an encephalomyelitis experimentally produced in mice with aviar. infectious bursal agent. Preliminary note. Clinica Veterinaria, 1980,103, 1980: 415-421.

CAMMARATA, G. - PARODI, M.C. - RAMPIN, T.: Encephalitis in mice due to infectious bursal disease virus. Archivo Veterinaria Italiano, 30,1979 : 119-124.

CHUI, C.H. - THORSEN, J.: Experimental infection of turkeys with infectious bursal disease virus and the effect on immunocompetence of infected turkeys. Avian Diseases, 28, 1984: 197-207.

HIROSE, M. - HIRAI, K.: Precipitating antibody against infectious bursal disease virus in egg yolk and serum of chickens. Research Bulletin of Faculty of Agriculture, Gifu University, 39, 1976: 165-170.

IDE, P.R.: A comparison of gel diffusion, fluorescent antibody and virus isolation methods in experimental and natural cases of infectious bursal disease. Canadian Journal of Comparative Medicine, 39, 1975: 183-190.

McFERRAN, J.B. - McNULTY, M.S. - McKILLOP, E.R. - COLLINS, D.S. - ALLAN, G.M.: Isolation and serological studies of infectious bursal disease virus from fowl, turkey and ducks. Demonstration of a second serotype. Avian Pathology, 9 , 1980: 395-404.

NAWATHE,D.R. - ONUNKWO, 0. - SMITH, I.M.: Serological evidence of infection with the virus of infectious bursal disease in wild and domestic birds in Nigeria. Veterinary Record, 102,1978 : 444.

OKOYE, J.0.A.: Infectious bursal disease of chickens. Veterinary Bulletin, 54 , $1984: 425-436$.

OKOYE, J.0.A. - UCHE, E.U.: Serological evidence of infectious bursal disease virus infection in wild rats. Acta vet. Brno, 55, 1986: 207-209.

OKOYE, J.O.A. - UZOUKWU, M.: An outbreak of infectious bursal disease among chickens between 16 and 20 weeks old. Avian Diseases, 25, 1981: 1034-1038.

PERELMAN, B. - HELLER, E.D.: Preliminary serological survey of infectious bursal disease in turkey flocks in Israel. Refuah Veterinarith, 38,1981 : 12-16.

PERELMAN, B. - HELLER, E.D.: The effect of infectious bursal disease virus on the Immune system of turkeys. Avian Diseases, 27, 1982: 66-76.

REED, L.J. - MUENCH, H.: A simple method of estimating $50 \%$ end-points. American Journal of Hygiene, $27,19: 493-497$.

RINALDI, A. - MANDELLI, G. - CESSI, D. - CERVIO, G. - VALERIA, A.: Aetiology of Gumboro disease. II. Pathogenicity of the virus to laboratory animals. 4th Congress of World Veterinary Poultry Association, Belgrade, 1970, p. 309-313.

VINDEVOGEL, H.: Resistance du pigeon aux virus de la maladie de Gámboro. Annales de Medicine Veterinaire, 123, 1979: 285-286.

WEISMAN, J. - HITCHNER, S.B: Infection attempts in turkeys and coturnix quail. Avian Diseases, 22, 1978: 604-609. 